\title{
Cikkismertetés: Kettőscélú intézkedések a kóros tápláltság visszaszorítására
}

\author{
Article review: Double-duty actions: seizing programme and policy \\ opportunities to address malnutrition in all its forms
}

Ismertetők: Varga Anita $₫$, Zámbó Leonóra

Országos Gyógyszerészeti és Élelmezés-egészségügyi Intézet

Ismertetett cikk: Hawkes C, Ruel MT, Salm L, Sinclair B, Branca F. Double-duty actions: seizing programme and policy opportunities to address malnutrition in all its forms. Lancet 2020;395:142-55. doi: 10.1016/S0140-6736(19)32506-1

Beküldve: $\quad$ 2020.03.03.

doi: $\quad$ 10.24365/ef.v61i2.565

Kulcsszavak: kóros tápláltság; alultápláltság; túlsúly; elhízás; táplálkozási szakpolitika

Keywords: malnutrition; undernutrition; overweight; obesity; food policy

A kóros tápláltság egyes formáinak kezelésére számos irányelv, program, irányítási struktúra és finanszírozási forma áll rendelkezésre, amely intézkedések általában különböző szervezetek kezében összpontosulnak. Ezzel szemben a kettős célt szolgáló intézkedések, holisztikus módon kívánják kezelni a kóros tápláltsági állapot minden formáját azáltal, hogy az alultápláltságot, a túlsúlyt és elhízást, valamint a táplálkozással összefüggő nem fertőző megbetegedéseket (diet-related noncommunicable diseases; DR-NCD) egyidejüleg vizsgálják. A közlemény tíz olyan kettős célt szolgáló intézkedést azonosít (pl. az új WHO által kiadott terhesgondozásra vonatkozó ajánlás feltérképezése; a szoptatás támogatására és védelmére létrejött programok áttekintése; az élelmiszertámogatások és -utalványok rendszerének újratervezése; új mezőgazdasági és élelmiszerrendszer-politikák kidolgozása az egészséges étrend támogatására), amelyek nagy valószínúséggel egyszerre csökkentik az alultápláltság, az elhízás és a DR-NCD kockázatait.
A cikk összegezi a kóros tápláltsági állapot különféle formáinak általános okaira vonatkozó bizonyítékokat, példákkal szemléltet néhány, az elhízással és a DR-NCD-vel kapcsolatos, alultápláltságra fókuszáló programok által okozott, nem szándékolt, negatív hatást (pl. elhízáshoz vezető élelmiszerjegytámogatás vagy csak az energiabevitel biztosítására fókuszáló agrárfejlesztések), és felhívja a figyelmet a kóros tápláltsági állapot több formáját is érintő, kettős célt szolgáló intézkedésekre. Megállapítható, hogy az alultápláltság, az elhízás és a DR-NCD összefüggésben vannak a korai életkorra jellemző táplálkozási szokásokkal, az étrend változatosságával, az élelmiszer-környezettel és a társadalmigazdasági tényezőkkel egyaránt. Néhány bizonyíték azt mutatja, hogy az alultápláltságra összpontosító programok nem megfelelő minőségú étrend követéséhez, elhízáshoz és a DR-NCD kockázatainak növekedéséhez vezetnek, különösen azokban az országokban, ahol a táplálkozási szokások gyors átalakuláson mennek keresztül. A közlemény a fenti 
bizonyítékokra építve stratégiai keretrendszert dolgozott ki a kettős feladatokat ellátó intézkedések megtervezéséhez, meghatározza az első lépéseket a célok eléréséhez [1. ábra], valamint felhívja a figyelmet arra, hogy az azonosított, kettős célt szolgáló intézkedések segítségével mielőbb lépéseket kell tenni a kóros tápláltság minden lehetséges formájának kezelése érdekében. Az előrehaladás felgyorsításához a táplálkozási szakembereknek felelősséget kell vállalniuk a kettős célt szolgáló intézkedésekért, valamint olyan paradigmát és gondolkodásmódot kell követniük, amely holisztikus megközelítéssel támogatja az intézkedések megtervezését, és a kóros tápláltsági állapot teljes spektrumát egyidejűleg kezeli.

1. ábra: Keretrendszer

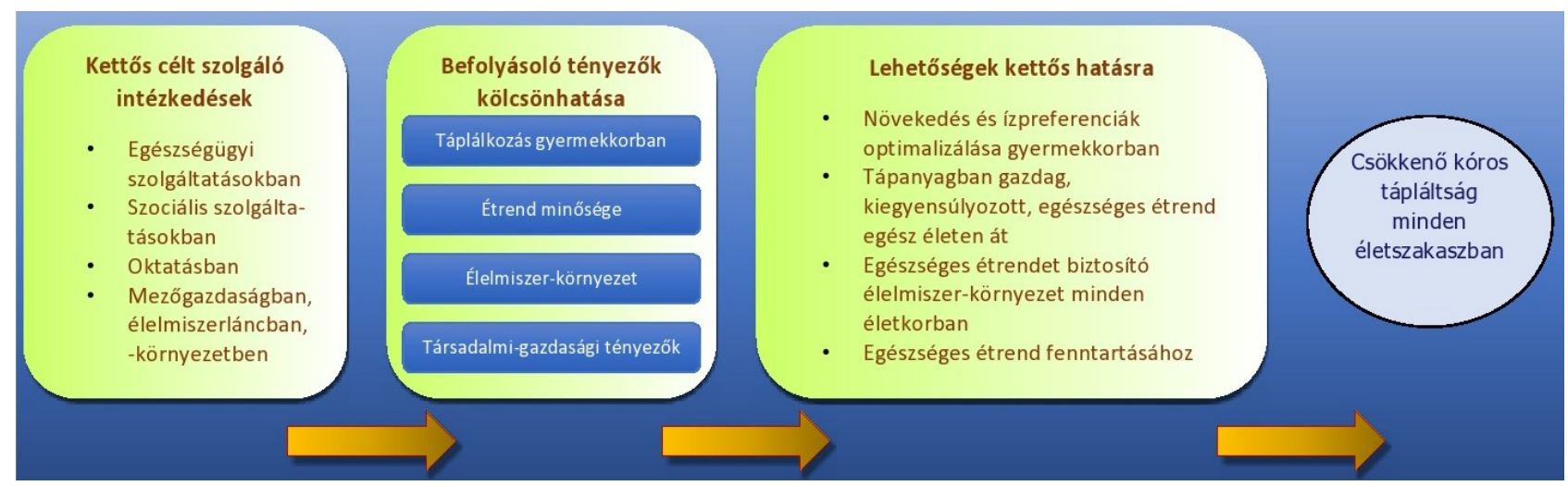

Forrás: az eredeti közlemény magyarra fordított változata

\section{TANULSÁGOK A HAZAI SZAKEMBEREK SZÁMÁRA}

A cikkben ismertetett bizonyítékok szerint a jelenlegi formában működő táplálkozáspolitikák és táplálkozási programok nem érik el a kitűzött célokat az ún. „új táplálkozási valóságban”, hiszen a kóros tápláltsági állapot különböző formáit rendszerint nem képesek egyidejűleg kezelni. Ebből kifolyólag hazánkban is szükségessé válik a táplálkozáspolitika és a táplálkozási programok hagyományos módon való megközelítésének újragondolása oly módon, hogy azok a kóros tápláltság minden formáját egyszerre legyenek képesek kezelni. A kettős célt szolgáló intézkedések megvalósításához stratégia és terv kidolgozására van szükség. Mindezek pedig alapvető változtatások végrehajtását követelik meg több területen, így az irányítás, a finanszírozás, a kutatás és a kapacitások terén is. 